\title{
Community Empowerment Through Plastic Waste Recycling To Improve Community Economy
}

\author{
Sukma Irdiana, Kusnanto Darmawan, Kurniawan Yunus Ariyono \\ STIE Widya Gama Lumajang \\ Email : sukmapasah@gmail.com
}

Submission :

Review :

Publication :

$1^{\text {st }}$ April 2020

$13^{\text {th }}$ June 2020

$28^{\text {th }}$ Augustu 2020

\begin{abstract}
Abstrak
The research aims to increase people's creativity in managing plastic waste into goods that have economic value. This research raises the issue of tackling plastic waste in Lumajang Regency. The object of this research was conducted in Pasrujambe District, Lumajang Regency. This research uses a qualitative approach with a case study model. Data collection in this study used two ways, namely interviews and observations. Furthermore, after the data was collected from the informants, analysis was carried out. The results of this study indicate that the Pasrujambe community consisting of PKK, Gerbangmas and PKK Friends enthusiastically participated in the training stages. Starting from plastic waste creation training, marketing training through social media to simple accounting training. The results of this training the community can make, among others, bags, plastic drinking containers, flowers, pencil cases, vases and so on. In addition, the community has also been able to market these products through FB, WA and Instagram and the community has also benefited from the plastic waste creation products they make.
\end{abstract}

Keywords: Community Empowerment, Waste Recycling, Economic Value

\section{INTRODUCTION}

Plastic waste is a global problem today. Plastic waste has been piling up in the world for a long time. Based on a report by the United Nations Environment Program (UNEP) on single-use plastic waste, no more than 400 million tons of plastic were produced in 2015. Of that number, 36 percent of which is for single-use packaging bags that we often encounter every day. The amount of plastic waste in the world has reached 300 million tons a year. Quoting from the BBC (8/8/2019), this amount of plastic waste if compacted will equal 10 times around the earth (Tim Publikasi Katadata, 2019).

The Indonesian government continues to work to reduce the amount of plastic waste. The government issued a trial policy to reduce plastic by charging a fee of two hundred rupiahs for consumers who want to use plastic bags for their shopping items. The government is working with various supermarkets to launch the program. The pilot program has actually had a positive impact on reducing plastic bags by $60 \%$. However, the program did not run smoothly, where various debates emerged in retail circles and finally the Government returned to making plastic bags free again. The government's steps did not stop there. Responding to the increasing amount of plastic waste, the Government is getting serious by cooperating with the World Economic Forum (WEF). The government is promoting the "plastic-free Indonesia" program by reducing waste by $70 \%$ by 2020 . In order to launch this 
program, the Government is working with entrepreneurs, the community and various government agencies (Bandung, 2019).

This program is fully supported by the Lumajang Regency Government by issuing Regent Regulation Number 56 of 2019 concerning Reducing the Use of Single-Use Plastics. This Regent Regulation contains areas for reducing the use of single-use plastics in government offices, private offices / companies, business actors, public facilities and social facilities. This regulation calls on the public to have the same rights and opportunities to play an active role in reducing the use of single-use plastics by inviting people to clean plastic waste or abbreviated as "Merak Berlipstik". Merak Berlipstik is one of the programs of the Lumajang Regency Government in reducing plastic waste (Redaksi, 2019).

Handling of plastic waste that is popular so far is the 3R (Reuse, Reduce, Recycle). Reuse is the repeated use of plastic items. Reduce is reducing the purchase or use of plastic goods, especially disposable items. Recycle is recycling items made of plastic. On the one hand, the discovery of this plastic has a tremendous positive impact, because plastic has advantages over other materials. According to Purwaningrum (2016), the advantages of plastic compared to other materials include strong, lightweight, flexible, rust resistant, not easily broken, easy to color, easy to shape, and good heat and electrical insulators. Therefore, plastic waste has many advantages if it can be used as a recycled product.

The waste recycling business has been going on for a long time and is a big business that is run systematically. To become a plastic waste recycling businessman, a person needs to build a good waste collection system, through mobilization and collaboration with the community, has skills in waste management, and knows the market share of plastic waste recycled products that are produced. Even though we still use plastic as the main raw material, the plastic waste creation business that the author offers is not as complex as the industrial plastic waste recycling business and this business can be done independently by the community. As a creative product, plastic waste creations have a promising commercial value. This product has a selling power that can generate business profits for the creation of plastic waste.

The prevention of plastic waste has become an economical item, which was done by Diana et al. (2018), Nadlifatin (2018), Martana et al. (2018), and Arico \& Jayanthi (2018), based on this service activity, it is found that there are still many people who do not understand the importance of creativity in managing plastic waste into economic goods.

The movement to use plastic waste into an economical item is one of the community empowerment movements in Pasrujambe. This is one of the strengths of the product that can be communicated to consumers. The production process involves many parties, from youth organizations, housewives, educators, and others. Running a plastic waste business means adding jobs and opening up possibilities for improving the welfare of the people of Pasrujambe. This will certainly increase the income of the people of Pasrujambe.

For this reason, the goal of community empowerment is to improve the economy of the Pasrujambe community by recycling plastic waste into economic goods.

\section{IMPLEMENTATION METHODS}

This research uses a qualitative approach with a case study model. By using this approach, researchers can conduct in-depth and specific exploration of cases or phenomena of plastic waste in Pasrujambe District, Lumajang Regency. This research uses a case study model because it wants to see how forms of community empowerment strategies are carried 
out by the people of Pasrujambe in overcoming plastic waste around their environment. Meanwhile, in this study the research informants were selected purposively, in which the researcher had certain considerations in selecting research informants. Data collection in this study used two ways, namely interviews and observations. Interviews were conducted by conducting direct interviews with research informants. Meanwhile, the observation technique used in this research is participant as observer, in which the researcher is present in the middle of the social unit being studied and informs about the aims and objectives of the research. Furthermore, after the data was collected from the informants, analysis was carried out. The stages of analysis in this study include data reduction, data reduction, data display, and conclusion / verification.

\section{RESULTS AND DISCUSSION}

The implementation of this community service activity regarding the empowerment of the Pasrujambe community in tackling plastic waste into economically valuable products lasts until June 2020. The targets in this empowerment are PKK, Gerbangmas and PKK Friends in Pasrujambe District. This community empowerment began with a review of the conditions in the Pasrujambe area. The purpose of this review is to find out firsthand what problems exist in Pasrujambe District. Based on a review of the condition of the Pasrujambe District area, it is known that the level of plastic waste in the area is quite a lot. According to Ms. Dian Nurwisudah KHP (Chairperson of the PKK, Pasrujambe District), the utilization of plastic waste into an economical item is one of the programs of the Regency and District TP PKK in tackling plastic waste. It's just that this program has not reached the lowest level of society and people still do not understand the importance of using this plastic waste. In addition, only a few people in Pasrujambe have expertise in managing plastic waste.

For this reason, it is necessary to compress training and assistance in managing plastic waste into an economical item. The community service implementation team tries to provide solutions to the Pasrujambe community by utilizing PKK, Gerbangmas and PKK Friends to gain expertise in managing plastic waste into economical goods.

This solution and guidance to the community was carried out in the Pendopo of Pasrujambe District at first as the opening of this activity. Then this activity was carried out there to each village for 7 consecutive days. The activity of the arbor there is carried out so that this guidance can directly reach the people in Pasrujambe District. Based on the total attendance, almost 100\% of PKK mothers, Gerbangmas and Friends of PKK came when the training was given. This activity aims to improve the skills of the Pasrujambe community in managing plastic waste into goods that have economic value.

Training on managing plastic waste into economical items, starts with providing training in arranging plastic waste into products such as flowers, vases, bags, cup holders, pencil cases and so on. This training is a special attraction for the community, especially mothers. This training is not only training to produce goods, but this training also teaches the public how to market their products to social media especially. Marketing taught through social media includes FB, Instagram and WA, because marketing through social media is the most economical and fastest. In addition to marketing training, the team also taught how to manage mothers' finances in order to make a profit. This training teaches simple accounting, this training is expected so that the public can control the finances of the products produced. So that people can know the pros and cons in producing goods.

This activity does not stop at providing training only. However, the team also conducted monitoring and evaluation of these training activities. By visiting places where 
mothers gather in their respective villages. Based on the monitoring and evaluation of the team, it was found that the skills of mothers and the sophistication of mothers in marketing their products were found. Although the level of sales of this product is not too fast, the benefits of this plastic waste product are there.

\section{CONCLUSION}

The Pasrujambe community participates in the use of plastic waste into an economical item. Community participation and participation in fighting plastic waste in Pasrujambe District can provide additional income for the community, especially mothers. It is not only the income that the community gets, but the skills and knowledge that they have never obtained can become a guide for society to be more advanced.

\section{REFERENCES}

Arico, Z., \& Jayanthi, S. (2018). Pengolahan Limbah Plastik Menjadi Produk Kreatif Sebagai Peningkatan Ekonomi Masyarakat Pesisir. Martabe: Jurnal Pengabdian Kepada Masyarakat, 1(1), 1. https://doi.org/10.31604/jpm.v1i1.1-6

Bandung, D. L. H. dan K. K. (2019, April). Upaya Pemerintah dalam Menangani Isu Sampah Plastik. Dinas Lingkungan Hidup Dan Kebersihan Kabupaten Bandung. https://badungkab.go.id/instansi/dislhk/baca-artikel/690/Upaya-Pemerintah-dalamMenangani-Isu-Sampah-Plastik.html

Diana, S., Marlina, M., Amalia, Z., \& Amalia, A. (2018). Pemanfaatan Sampah Plastik Menjadi Produk Kerajinan Tangan Bernilai Ekonomis Bagi Remaja Putus Sekolah. Jurnal Vokasi - Politeknik Negeri Lhokseumawe, 1(1), 68-73. https://doi.org/10.30811/vokasi.v1i1.570

Martana, B., Nashir, A. K., Pradana, S., \& Sugianto. (2018). Pengolahan Sampah Plastik Menjadi Produk Lainnya Sebagai Upaya Peningkatan Ekonomi Masyarakat. Prosiding Seminar Hasil Pengabdian (SNP2M) 2018, 2018, 23-25.

Nadlifatin, R. (2018). Pengolahan Limbah Plastik Menjadi Produk Kerajinan Tangan Untuk Meningkatkan Ekonomi Masyarakat Sendang Dajah. Jurnal Abdikarya : Jurnal Karya Pengabdian Dosen Dan Mahasiswa, 1(1), 98-102. https://doi.org/10.1017/CBO9781107415324.004

Purwaningrum, P. (2016). Upaya Mengurangi Timbulan Sampah Plastik Di Lingkungan. Indonesian Journal of Urban and Environmental Technology, 8(2), 141. https://doi.org/10.25105/urbanenvirotech.v8i2.1421

Redaksi. (2019). Launching Peraturan Bupati Lumajang Nomor 56 Tahun 2019. beritaLima. https://beritalima.com/launching-peraturan-bupati-lumajang-nomor-56-tahun-2019/

Tim Publikasi Katadata. (2019, September). Pentingnya Pengelolaan Sampah Plastik. Tim Publikasi

Katadata. https://katadata.co.id/timpublikasikatadata/berita/5e9a4e54bb50f/pentingnyapengelolaan-sampah-plastik 